\title{
Analyzing Citizens' Propensity to Confront and Report Corruption: Evidence from Uganda
}

\author{
Deborah Sarah Nakirijja, Liu Oijun \\ School of Public Administration, Huazhong University of Science and Technology, \\ No. 430073 Hubei Wuhan PR. China
}

${ }^{*}$ Corresponding author email: deborahsn1991@gmail.com

Received: 07 July 2020 / Revised: 04 September 2020 / Accepted: 07 December 2020 / Published: 15 December 2020

\begin{abstract}
Corruption as a phenomenon has attracted significant interest from researchers who mostly focus on the causes and underlying effects of corruption at the national and societal levels. Many interventions have also been designed to reduce corruption to a bare minimum but there is a dearth of literature looking at citizen's intervention to address the problem. This study examined the attitudes of citizens towards corruption by looking at the factors that influence citizen's willingness to report and confront corruption in Uganda. Drawing on data collected from the survey of 251 citizens in Uganda, this research found that corruption tolerance by citizens is low, but the willingness of participation in anti-corruption campaigns is not correspondingly high. However, low corruption tolerance alone does not explain why people don't report corruption. Awareness of corruption and trust in government's and civil society anti-corruption efforts and laws was also identified as a major influence to citizen's willingness to confront and report corruption. In addition, higher confidence in the government's anti-corruption strategies and laws leads to lower corruption tolerance and stronger willingness to confront and report corruption. The study suggests that a successful campaign of anticorruption must involve enhancing understanding of what constitutes corruption and building confidence in the Government's strategy on anticorruption.
\end{abstract}

Keywords: Citizen Trust, Tolerance, Awareness, Report, Confront, Corruption

\section{Introduction}

Corruption is, it would appear, one of the great evils of our time. Citizens are appalled by it, international organizations have created reform agendas to tackle it and politicians earnestly claim to want to reduce it (Hough, 2013). Corruption in many ways has proved to be a cancer in many societies that it's most pronounced. It affects almost every sphere of life; many researchers and development organizations have come up to define the term corruption with a similar area of emphasis "abuse of public office for private gains." Transparency International (Martini, 2013) talks of 'the abuse of entrusted power for private gain', whilst the Organization for Economic Co-operation and Development (OECD) believes corruption to be 'the active or passive misuse of the powers of public officials (appointed or elected) for private financial or other benefits.' (Kaufmann, 2005), writing on behalf of the International Monetary Fund (IMF), believes corruption to be 'the abuse of public power for private benefit' although he also broadens this slightly by adding that it can be thought of as 'the abuse of authority or trust for private benefit'. The World Bank, 1994, meanwhile, uses very similar language ('the abuse of public office for private gain.' All these definitions point to the fact that corruption is a behavior that deviates from the formal rules of conduct governing the actions of someone in a position of public authority because of private motives.

Copyright (C) 2020. The Author(s). Published by AIJR Publisher.

This is an open access article under Creative Commons Attribution-NonCommercial 4.0 International (CC BY-NC 4.0) license, which permits any non-commercial use, distribution, adaptation, and reproduction in any medium, as long as the original work is properly cited. 
Analyzing Citizens' Propensity to Confront and Report Corruption: Evidence from Uganda

According to prior research in Hong Kong (Ting Gong and Hanyu Xiao, 2017) Governments and their anticorruption agencies are generally aware of the importance of engaging the public in fighting corruption and the need to provide channels for citizens to report corruption. The success by government efforts at combating corruption hinges on the extent to which they are able to attain public support. If citizens view their government as corrupt and dishonest, they become cynical about political life and, as a result, less likely to participate in democratic governance (Neshkova \& Kalesnikaite, 2019). Furthermore, Fung, 2015 in their study demonstrated how elections alone may fail in a democratic society as an instrument of accountability if voters' disappointment with corrupt politicians turns into dissatisfaction with democracy as a system.

The study makes two assumptions based on factors influencing citizens' propensity to confront and report corruption in Uganda. There has not been a survey on citizens' propensity to confront and report corruption specifically in Uganda. Therefore, the purpose of this study was to analyze what factors that influence citizen willingness to confront and report corruption cases in Uganda. The three variables of trust, corruption tolerance and corruption awareness were measured to explore the attitudes towards corruption; and its main influencing factors on citizens' propensity to report corruption cases. The study noted however that mobilization for collective action to fight corruption depends on citizens' capacity and willingness to pursue social accountability (socially embedded anti-corruption).

\section{Empowerment Theory}

Discussions revolving around notions of empowerment and empowerment theory advanced in the 1960s and 1970s out of concern for the powerlessness of specific groups in society (Naidoo, 2015) this research paper focuses on Zimmerman's notion of empowerment, in which professionals (law enforcers) are encouraged to engage as 'collaborators' rather than 'authoritative experts.' Empowerment is both a value orientation for working in the community and a theoretical model for understanding the process and consequences of efforts to exert control and influence over decisions that affect one's life, organizational functioning, and the quality of community life (Zimmerman, 2000). At the community level of analysis, empowerment may refer to collective action to improve the quality of life in a community and to the connections among community organizations and agencies. Informing and sensitizing the public through raising public awareness about the problem has increasingly become over the recent years one of the most important aspects in the anticorruption field in Europe. Figure 1 below explains the empowerment at the community level which explains the study aspects and how to influence citizens' propensity to confront and report corruption in Uganda.

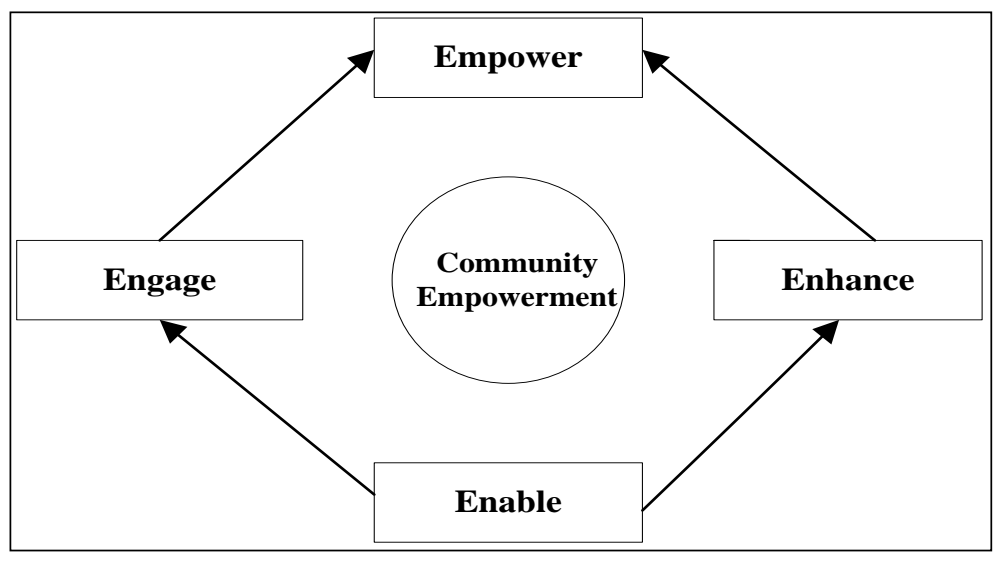

Figure 1: The Empowerment Theory

The empowerment theory in this study involves a process of enhancing, enabling and engaging citizens in all interventions undertaken to fight corruption because they are affected most during access to basic public services. The citizens have an active role in the change process, not only for implementing an intervention, but also in setting the agenda. A distinction between empowering processes and outcomes is critical in order to clearly define empowerment theory (Levin, 1987; Zimmerman, 2000). Empowering processes are ones in which attempts to gain control, obtain needed resources, and critically understand one's social environment are 
fundamental. The process is empowering if it helps people develop skills so they can become independent problem-solvers and decision-makers.

In addition, the empowerment approach to intervention design, implementation, and evaluation redefines the professional's (leaders) role relationship with the target population (citizens). The professional's role becomes one of collaborator and facilitator rather than expert and counselor. As collaborators, leaders learn about the participants through their cultures, their worldviews, and their life struggles (Zimmerman, 2000). The professional works with participants or citizens instead of advocating for them. The skills of the professional or leader are not necessarily imposed to the community people but rather they work hand in hand. This enhances their involvement in community affairs or matters that concern them.

Fawcett, Francisco, Schultz, \& Richter, 1995 describe eight case studies that demonstrate innovative roles for professionals interested in promoting empowerment among those with whom they are working. They provide a framework of empowering strategies that focus on capacity building for individuals and groups, and creating environments that support the development of empowerment. Empowering processes at the community level might include accessible government, media, and other community resources. Empowered outcomes refer to operationalization of empowerment so we can study the consequences of citizens' attempts to gain greater control in their community, or the effects of interventions designed to empower participants (Zimmerman, 2000). These conceptual definitions also suggest that participation with others to achieve goals, efforts to gain access to resources, and some critical understanding of the sociopolitical environment is basic components of the construct.

The empowerment theory guided the study on possible ways and suggestions to quip the respondents with the necessary requirements to demand for accountability in governance and access to public services. Since the empowerment theory suggests that community participants have an active role in the change process, not only for implementing a project, but also in setting the agenda, the same principle was adopted through the study in order to eliminate chances of unethical behaviors like corruption. A distinction between empowering processes and outcomes is critical in order to clearly define empowerment theory.

\section{Conceptual Framework}

Concerning the citizen propensity to report and confront corruption cases in Uganda, the framework (Figure 2) indicates that citizen trust in Anti-Corruption agencies whether Government or Not for profit Organizations (NGOs) and Civil Society will influence their willingness to report. In addition, the knowledge about what entails a corruption act and also awareness of what corruption is influences citizens' willingness to confront and report corruption in Uganda, thus;

It should be noted that there are some mediating variables that influence citizens' propensity to confront and report corruption cases in Uganda. These according to the study are influence of the media through exposing and reporting cases involved in corruption. Civil society organizations also play an important role in organizing and representing citizens in sensitizing on what entails a corruption act, in addition to reporting and exposing practices that entail corruption in collaboration with other agencies like the Police. Religion is also highlighted as an institution that prohibits moral degradation like acts of corruption which holds individuals involved in the practices accountable to God. This also influences citizens to confront corruption in that line. 


\section{Mediating Variables}

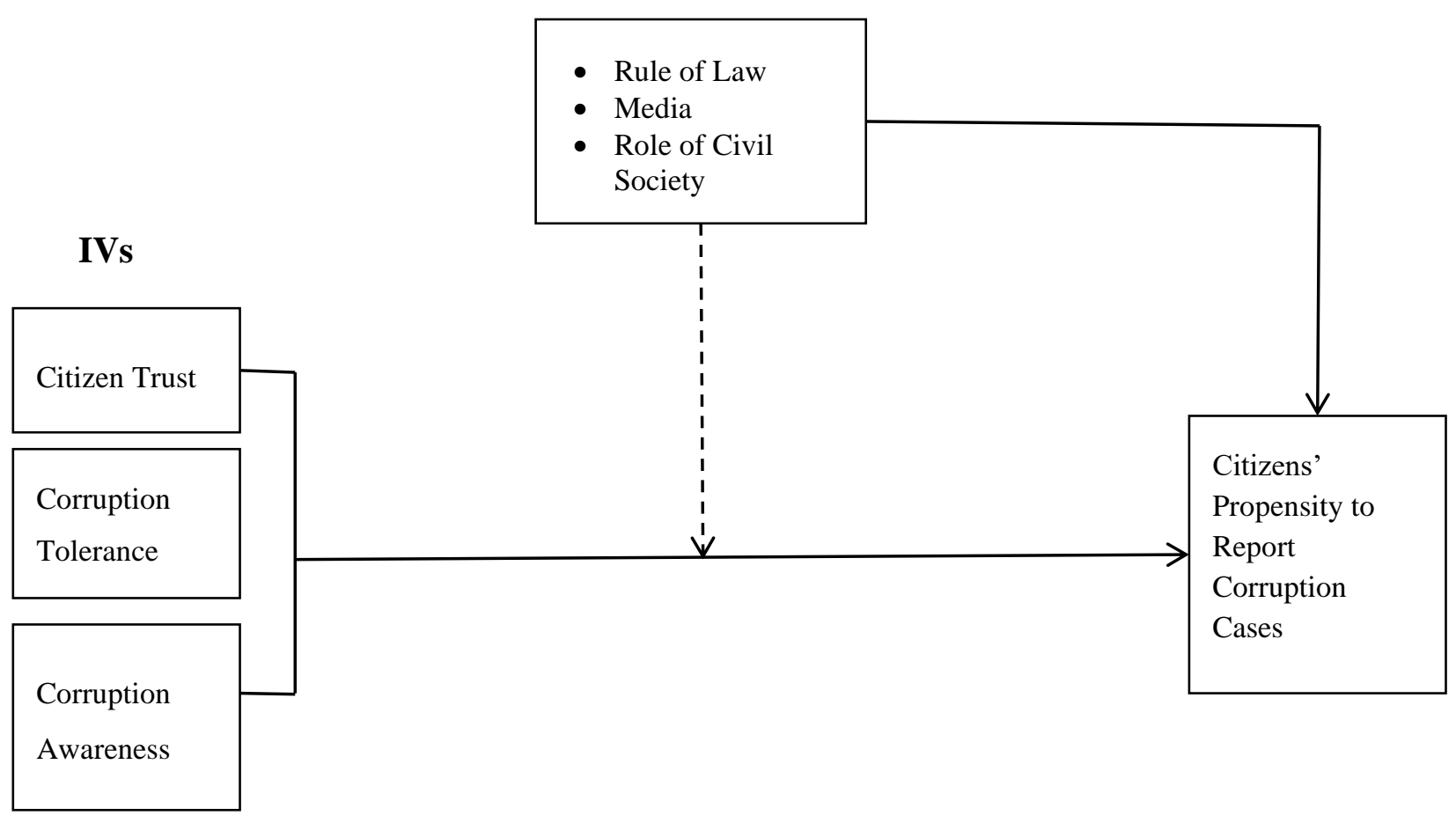

DV

Figure 2: Conceptual Framework

\section{Research Context}

\subsection{Why Uganda?}

Although corruption is a global phenomenon which cuts across both developed and developing countries alike, there are strong suggestions that its adverse effects are felt more severely in developing and transitional economies in comparison to more industrialized countries where political, social and economic institutions are more strongly developed and the illegal proceeds from corruption are more likely to be re-invested locally. Uganda has regularly featured as one of the world's most corrupt countries within Transparency International surveys (Corruption Perception Index). Transparency International's 2017 Corruption Perceptions Index ranks Uganda 151st out of 181 countries and territories, with a score of 26 out of 100, indicating a perception of widespread and endemic corruption. The country ranks 33 out of 49 countries in the Sub-Saharan Africa region. This estimated extent of corruption in Uganda is simply overwhelming, as a result of the staggering figures involved in just those stolen public funds which have been discovered.

The President of Uganda on December 2018 launched the anti-corruption unit at the state house for the general public to report and expose corruption cases but this has not yielded much so far. Yet, we know little about the determinants of citizen participation in the anti-corruption efforts and whether it follows patterns similar to Government established agencies and civil society. Much as the Government of Uganda has made efforts through some laws and policies however, the implementation of corruption prevention and detection and of anti-corruption enforcement has been particularly weak. In Uganda, Civil Society and media have played a key role in exposing corruption cases yet they have been subject to closure by the government. To tackle the challenge posed by anti-corruption efforts, the Government of Uganda should consider adoption and 
implementation of good enforcement practices that include the role played by CSOs in the pursuit of good governance.

In recent years, the government of Uganda has been vocal about fighting corruption in the country. A series of laws and policies aimed at reducing corruption and its pervasive effects have been established, but the lack of implementation and enforcement of these rules and policies have raised doubts about the seriousness of the government efforts as well as of its political will to actually change the situation in the country (IGG, 2003). A new National Anti-Corruption Strategy (NACS) was launched in 2008. This strategy is a 'five-year plan designed to make a significant impact on building the quality of accountability and reducing corruption levels in Uganda'. It focuses not only on government structure and systems, but also on people and on rebuilding a culture of integrity (Directorate of Ethics and Integrity, 2008). Other measures taken by the government include the new Anti-Corruption Act in 2009, the 2007 declaration signed by Ugandan, Kenyan and Tanzanian anticorruption authorities to deny safe haven to corrupt persons and investment in illicit funds. According to respondents to the National Integrity Survey conducted by the Inspectorate of Government in 2008, the most recurrent forms of corruption in the country include the payment of bribes (66\% of the respondents); embezzlement of public money (15\%), nepotism (5\%), and favoritism (3\%) (Martini, 2013).

Given the increased salience of corruption in the modern world (Nichols, Berliner, Damage, \& High, 2007), it comes as little surprise that in recent times social scientists have also conducted ever more analysis of corruption's underlying causes, its effects, and naturally what policy-makers have tried to do (and indeed should do in the future) to try and counteract it (Hough, 2013; Kaluya \& Elliott, 2018; Kaufmann, 2005; Morales, 2011; Mudacumura, 2014). And yet, as any student of politics in more or less any part of the world knows (Hough, 2013), these efforts have been at best only partially successful. These critics have suggested the need for the design of governance reforms to be more strongly located within analyses of the particular political cultures of specific countries, if they are to be successful, and have also stressed the need to complement institutional level governance and anti-corruption reforms with the active engagement and participation of civil society within the struggle to combat corruption.

\subsection{Citizens' Participation in Anti-Corruption}

Drawing reference from the definitions of corruption, International development agencies and donor countries are demanding participatory good governance in local government bodies in developing countries to maximize outcomes from development programs implementations (The World Bank, 1994). The reasoning behind such demand is that where there is good governance, "citizens and State officials can interact to express their interest, exercise their rights and obligations, work out their differences and cooperate to produce public goods and services" (See Brinkerhoff \& Wetterberg, 2015). Researchers (Jilke, 2017; Ocheje, 2018; Song \& Meier, 2018) have argued that effective people's participation can ensure accountability, transparency, and legitimacy, that is, good governance, during implementation of any development programs, which consequently ensures effective development. Late Kofi Annan, former Secretary General of the United Nations, once declared that "good governance is vital for the protection of the rights of citizens and the advancement of economic and social development (Krawczyk \& Sweet-Cushman, 2017).”

Broadly, citizen participation has been defined as individual and collective involvement of residents to affect conditions in their community (Tarling, 2005). Public participation in administration is an act of direct democracy, where citizens voice their opinion on specific issues faced by their communities. It is not an alternative or substitute for other channels of representative democracy such as voting in elections rather, it complements them (Fung, 2006). However, participation is not a one-sided event; it is a process that involves service providers and service receivers (Gaventa, 2004). In regard to the efficacy attributed to these two 
Analyzing Citizens' Propensity to Confront and Report Corruption: Evidence from Uganda

elements, there is consensus between social researchers and donors; they stipulate that good governance can be achieved by incorporating the community's knowledge into their social and political life (Gaventa, 2004).

Successful anti-corruption programmes rely on politicians building broader coalitions of support with the citizens and also sticking with their policies in to the long-term (Hough, 2013). Whilst high-profile anticorruption commissions or national campaigns to clean up public life may sound laudable and indeed be well intentioned, such initiatives all-too-often prove ineffective (and at times they can actually make problems worse) especially if politicians can't carry respective stakeholders (i.e. civil servants, political opponents, civil society organizations and not to mention the citizenry) with them. Research by (Nelson \& Afonso, 2019) on what determinants including form of government, affect the probability that a corrupt act will occur indicate that municipalities with the council-manager form are 57 percent less likely to have corruption convictions than municipalities with the mayor-council form. Poverty and/or low levels of economic development are correlated with a greater prevalence of corruption. In addition, bureaucracy that is size of government increases, the potential rewards/benefits of corruption increase.

\section{Determinant Variables}

\subsection{Citizens' Trust}

Citizen trust in government has been an important topic of study for public administration and political science scholars for many years (Bissessar, 2014; Fung, 2015; Grimmelikhuijsen \& Knies, 2017; Kaluya \& Elliott, 2018; S. Van De Walle, Roosbroek, \& Bouckaert, 2008). To understand the multidimensionality of perceived trustworthiness in this study, we will first provide a definition of trust in general. Given the complexity of the concept, and the multiple disciplines that have embarked on trust research, defining trust is not easy. Understanding why and how people trust others has been a central focus of research for psychologists, sociologists, political scientists, economists, and organizational scientists. Across disciplines and even within disciplines, a myriad of definitions, concepts, and operationalization are being used in research. For (Jerusalem, 2013; Laegreid, 2016), trust is a threefold relationship, in which A trusts B to do X. A expects B to do a certain thing which is in his/her interest. In case of citizen trust in government, this threefold relation yields a risk as citizens are uncertain as to whether government organizations actually carry out the tasks they are entrusted to. Risk becomes relevant when governments exert a certain degree of power over citizens, which can either be used properly or abused.

According to a study by (Grimmelikhuijsen \& Knies, 2017) assessing trust at the meso level, i.e. trust in a specific government organization may help in addressing public trust. Measuring trust in government organizations better allows us to identify particular organizational contexts that relate to the antecedents of trust in that organization. As a consequence, understanding trust in specific organizations can help to develop more appropriate models for public trust in general. While exploring the role of transparency and trust in South Korea, Park \& Blenkinsopp, 2011 suggests that Governments can improve institutional trust by adopting new technologies such as government websites, suggesting that ICT-based public service delivery can be one of the institutional enablers for enhancing trust in moral accountability, through making its process more transparent and reducing public officials' discretionary power. Trust in government or public services is typically measured in terms of citizens' subjective judgments based on their experience, suggesting that citizens' trust will arise when a government or its public service is viewed by citizens as competent, reliable and honest, while also meeting their needs (Park \& Blenkinsopp, 2011).

Furthermore, for Gillanders \& Neselevska, 2017 trust is important for a wide range of macro-level outcomes including governance and infrastructure. Trust has also been shown to matter for investment behavior, labor market participation, and human and physical capital accumulation (V. De Walle, 2010). Interpersonal trust is also important in terms of support for and the effectiveness of redistributive policies a high level of trust has 
the potential to make a society better off and more equal. We show that experiencing bribery in the course of one's interactions with the public sector lowers one's trust in big private corporations, small businesses and local traders. In a study by (Park \& Blenkinsopp, 2011) showed that Transparency and trust are seen to moderate or mediate the relationship between corruption and satisfaction. Gaining citizens' trust is similarly a high priority challenge for Government. However, according to (S. Van De Walle et al., 2008) citizens distrust the public sector because governments have not fully embraced e-government, because the third sector is not sufficiently involved in delivery, because government has not developed partnerships to deliver services, because politicians have too much or too little say in appointing leading official

\subsection{Corruption Tolerance}

In order to understand attitudes towards corruption (tolerance/acceptance of corruption) the study refers to the extent to which people tend to accept corruption, indicating how people understand rules and social ethics and their perceptions of deviant behaviors. In China for example, the concept of 'corruption tolerance' was first put forward in an editorial entitled 'Anti-corruption is a Tough Battle of Chinese Social Development' in 2012 where the editorial stated that corruption cannot be completely cured in any country, and the key is to control it to the extent that the public find acceptable (Guo \& Tu, 2017). Brinkerhoff \& Wetterberg, 2015 in their study look at corruption tolerance in the form of social accountability (vertical accountability); which refers to actions by civil society and citizens to push officeholders to report on and answer for their actions; this category is the demand side of accountability. In addition, the study however acknowledges that, groups (citizens) with privileged access to state resources are unlikely to share the concerns of deprived groups for service delivery accountability and may oppose their demand making in reporting a particular case on corruption.

However, (Kahana \& Qijun, 2010) corruption is endemic if the heads of government bureaucracies are corrupt in the procedures and criteria for personal advancement in the government bureaucracy. The corruption that is described the study is thus contrary to descriptions in principal-agent models that take for granted that the source of corruption is the behavior of subordinates and describe principals as necessarily principled. It is indeed the subordinates who may be principled to different degrees but nonetheless by the rules of behavior bribe their superiors to improve prospects for personal advancement. In addition, Guo \& Tu, 2017 through large sample surveys of Chinese civil servants, found that corruption tolerance of civil servants is low, but the enthusiasm of participation in anti-corruption campaigns is not correspondingly high. From cognition to attitude to behavior, they gauge respondents' corruption tolerance more comprehensively

\subsection{Corruption Awareness (Laws and policies)}

In Uganda, Citizens across the country are involved in participatory approaches to developing priorities for the national budget through a program involving the finance ministry, national NGOs, and district and local governments in order to improve on transparency in budgetary allocation and distribution (Gaventa, 2004). Transparency is one of the practical measures taken to curtail corruption, acting as a deterrent against corrupt behavior by promoting citizens' vigilance, thus deterring public officials from misusing public service to attain private gain (Park \& Blenkinsopp, 2011). The capacity and motivation of citizens to occupy the available space, aggregate and voice their concerns (awareness of corruption), and participate with state actors in assessing service delivery performance and problems are critical (Brinkerhoff \& Johnson, 2009; Guo \& Tu, 2017). Less understanding about corruption results in higher corruption tolerance and lower enthusiasm to participate in fighting against corruption (Guo \& Tu, 2017). 
Analyzing Citizens' Propensity to Confront and Report Corruption: Evidence from Uganda

\section{Mediating Variables}

\subsection{Role of the media}

In a literature review study by (Tang, Ding, \& Xu, 2018) in China, findings show that anti-corruption mechanisms have gradually changed from the campaigns against corruption (1950s-1980s) to institutionalized anti-corruption (1990s) and finally to anti-corruption through new media platforms (since the 2000s). They have emphasized the importance of the Internet, especially the role of new media (e.g., Weibo and WeChat) and other modern technology tools in anti-corruption efforts (Tang et al., 2018). Measuring the pervasiveness of corruption presents a challenge, because by nature it occurs away from the public eye (Porumbescu, 2016; Sheryazdanova \& Butterfield, 2017). While the media manages to publicize and expose some corruption cases, especially those involving high-ranking officials, most abuse goes undetected.

However, residents can either overestimate the extent of corruption because of the media coverage of grand corruption scandals or underestimate it because they have developed tolerance toward it (Neshkova \& Kalesnikaite, 2019). Perception of corruption, on the other hand, may reflect a broader array of factors, including the information that individuals gather from the news media on high-profile cases (Porumbescu, 2016). Governments and businesses must do more to encourage free speech, independent media, political dissent and open and engaged civil society

\subsection{The role of Civil Society}

Although there is no easy definition of the concept in the global arena, due to differences in forms of social organization, culture and political tradition, civil society is commonly referred to as a collection of social relations that exist at the interface between the state and private sector (Rubalcaba Medina, 2017). Much contemporary democratic theory rests on the claim that functioning democracies require a "civil society" network of nongovernmental organizations that allows men and women to both discuss their common interests and form organizations that can pressure the state on the basis of those interests (Riley \& Fernández, 2014). According to a study by Paxton 2002, civil societies exists a result of both causes and consequences of liberal democracy influenced by long term cultural and economic factors (Riley \& Fernández, 2014).

Civil Society Organizations (CSOs) in Uganda represent various agendas that include: human rights organizations; anti-corruption coalitions; gender-based groups; child-focused groups; faith-based institutions; health, education, conflict and peace-building coalitions; and a number of national networks. These are primarily categorized as Non-Government Organizations (NGOs), trade unions, Community Based Organizations (CBOs), community groups, and professional associations (Fourie \& Kakumba, 2011). Freedom of association is guaranteed by Uganda's constitution but is often restricted in practice; nevertheless, civil society is vibrant. The government continued to harass civil society groups that advocate for sensitive issues, such as combating corruption, transparency in the oil sector. Many of these groups receive a lot of their funding from abroad. The bond between citizens and political institutions has weakened in the United States and other industrialized democracies (Fung, 2015).

Over recent years the World Bank has argued that the role of civil society is integral in promoting good governance and anti-corruption campaigns. Civil society organizations can play a unique role in mediating between the government and the public (World Bank, 2006). Since corruption is an element which occurs in secret, through diagnostic surveys and investigative journalism by the media, civil society organizations can increase public understanding of the magnitude and pattern of corruption, which could form a useful reference point for decision makers. However, since they themselves are not immune to corruption, it is important that they are subjected to public scrutiny for transparency and accountability purposes (Hillier, 2019). Brinkerhoff \& Wetterberg, 2015 take a critical look at the reliance on civil society and engaged citizens as vehicles for 
sustainable accountability and responsiveness in order to shed light on the contextual factors that affect how and under what conditions such approaches and tools can achieve intended results

Citizens and governments are coming together in new ways to participate, deliberate, and develop solutions to pressing social, economic, and community development issues (Gaventa, 2004). An active civil society acts as a voice for the citizens to provide and demand for accountability from government thus promoting transparency. This is because an active civil society in the governance makes the Government more accountable to its citizens; therefore, they need to be empowered.

\section{Data and Measurements}

To understand what factors, influence citizen's propensity to confront and report corruption, data was obtained from an original survey that was conducted in Uganda. The survey employed the use of both survey questionnaires and interviews with the relevant respondents. During the survey, field visits were made to interview local residents (citizens) to obtain detailed information on their perceptions of corruption and of the government and civil society anti-corruption performance. We managed to sample respondents from all the four regions of Uganda to make a proper generalization of the findings. Majority of the respondents interviewed as shown in table 1 below were from central (57.2\%) and western (15.2\%) regions of Uganda. These regions were easily accessible for the researchers. The respondents were selected through a purposive and snowball sampling process, according to age (those below 18 years were omitted from the study). The study used three variables of citizen trust, corruption tolerance and corruption awareness. A total of 251 valid questionnaires were obtained. The trust index was composed of three items that characterize trust in government and civil society anti-corruption institutions trust in the judiciary and police. The tolerance index identified how citizens perceive a corrupt act/case and accept it in their society. Lastly the awareness index involved knowledge of laws that govern anti-corruption. Table 1 below shows the distribution of respondents per region of origin who participated in the study. Majority of the respondents came from the central region.

Table 1: Number of respondents interviewed by originality

\begin{tabular}{lrr}
\hline Region & Frequency & \multicolumn{2}{c}{ Percentage (\%) } \\
\hline Central & 143 & 57.2 \\
East & 34 & 13.6 \\
North & 13 & 5.2 \\
South & 11 & 4.4 \\
West & 38 & 15.2 \\
& & \\
\hline
\end{tabular}

In Figure 3, respondents were asked to rank the most problems facing Uganda today with 1 (most serious) and 7 (least serious). It is with no surprise that corruption, poverty and unemployment were ranked as the major problems facing the country. There is a link between corruption and poverty which is also acknowledged by one of the respondents interviewed;

"The reason why most people are poor and lack the basic social services is because of corrupt leaders that accumulate more wealth for their stomachs especially those in public offices. A lot of resources that would have been channeled to help the public are swindled for private purposes" 


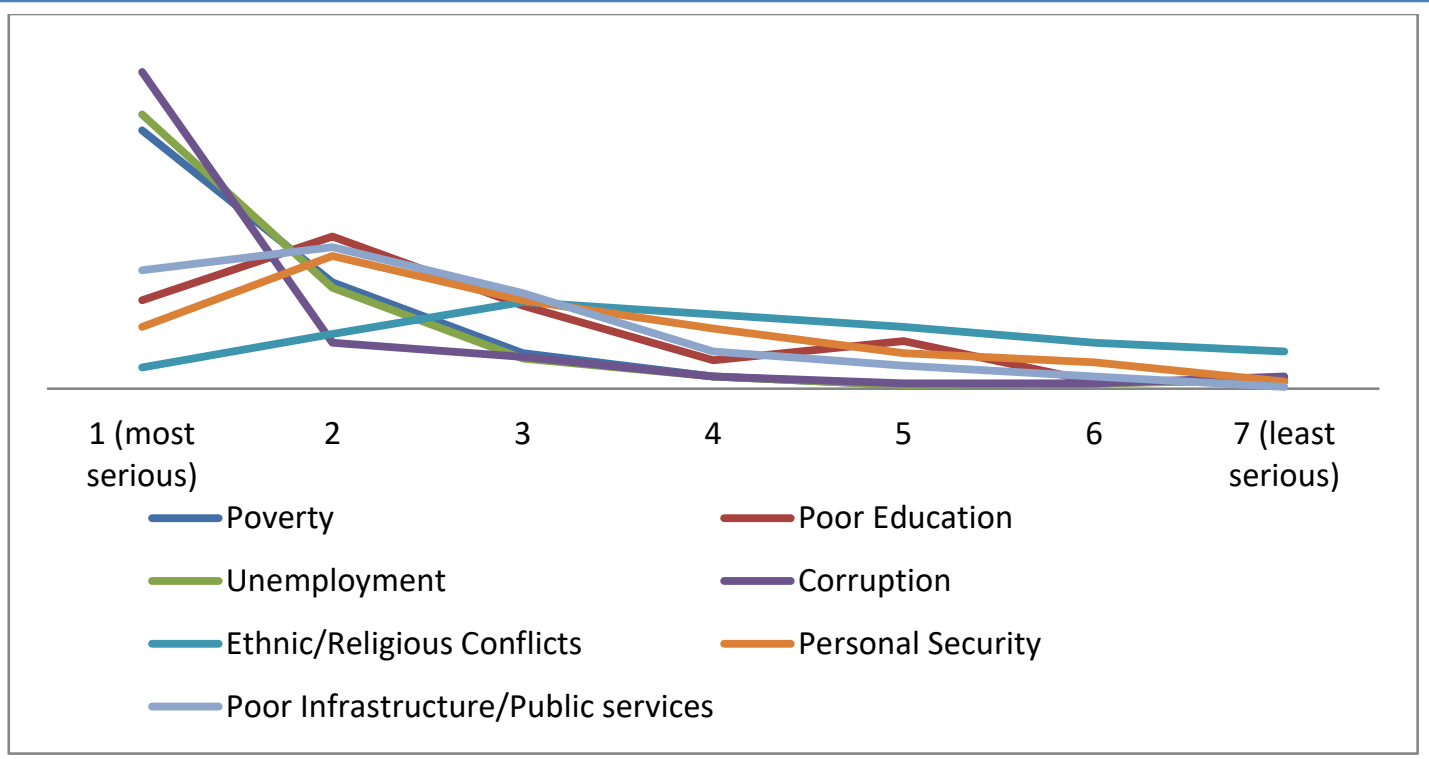

Figure 3: Citizens' perception on the major problems affecting Uganda.

Respondents were also required to rank the most effective institution in the fight against corruption and as figure 4 below shows, the media, Anti-Corruption Coalition Uganda, Transparency International Uganda and Inspectorate of Government were ranked in that order and very effective and effective in the fight against corruption. Findings also show majority of the respondents ranked the police and courts of law as very ineffective and ineffective respectively with the view that they are the top corrupt institutions in Uganda through accepting bribes in their operations. These findings agree with (TI-Kenya, 2017) where the Police in Tanzania, Kenya and Uganda, Judiciary in Uganda, and the Police in Rwanda took the top five positions as the most bribery prone institutions in the region. This explains why most respondents $(78.8 \%)$ in the study reported not reporting corruption cases to the authorities and only $12.4 \%$ recorded doing so. When asked why, most respondents feel like nothing will be done even if they report. In relation, from the global corruption barometer by Transparency International (TI, 2019), when asked why respondents around the world did not report any of the bribery incidents they encountered, a quarter of the respondents across the region felt no action would be taken to resolve their corruption complaints.

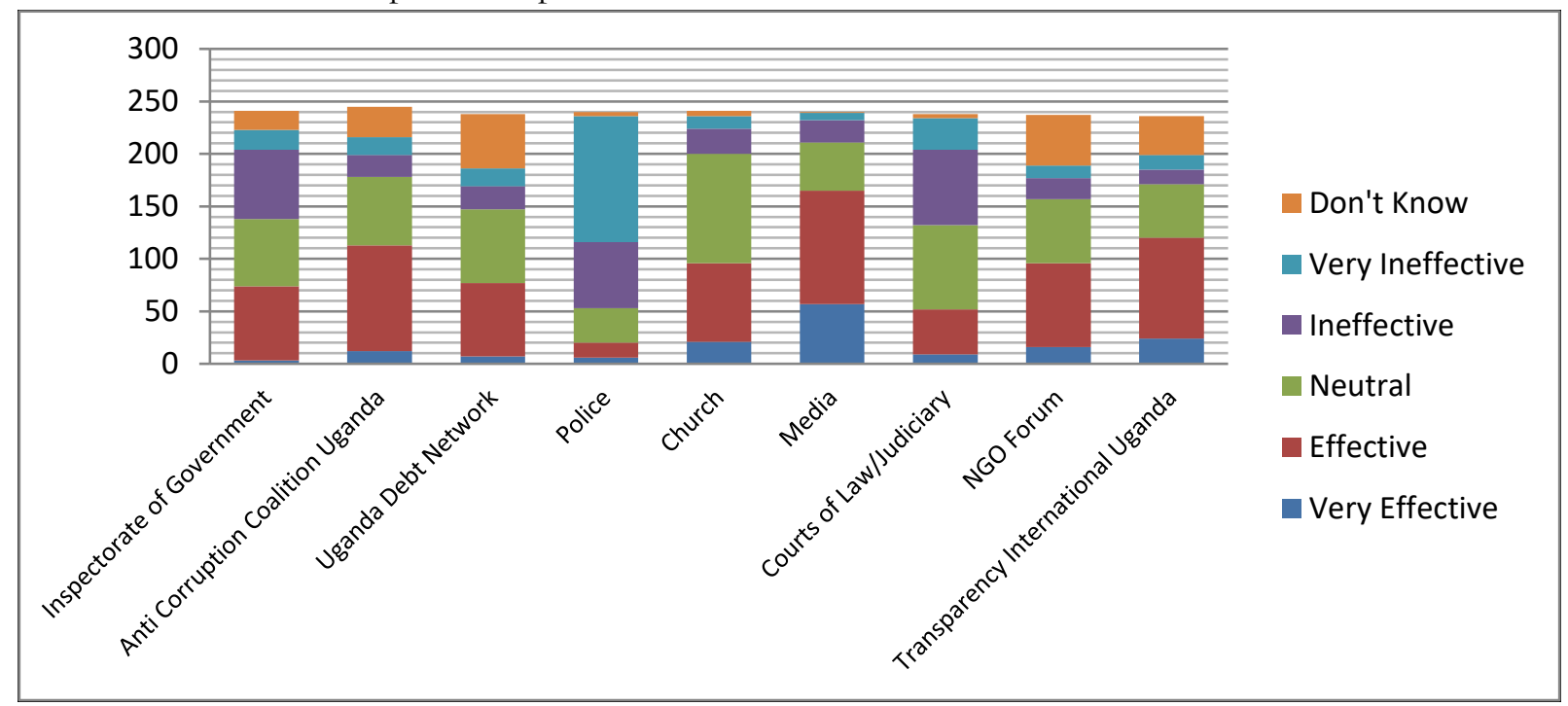

Figure 4: Citizens' ranking on the most effective institution in the fight against corruption 
In order to understand the dynamics in citizens' willingness to report corruption, the study makes two assumptions based on factors influencing citizens' propensity to confront and report corruption in Uganda. The three variables of trust, corruption tolerance and corruption awareness were measured to explore the attitudes towards corruption; and its main influencing factors on citizens' propensity to report corruption cases in Uganda. The vast majority of scholars do not distinguish between attitudes and behavior when exploring people's corruption tolerance (Choi \& Robertson, 2018; Park \& Blenkinsopp, 2011; Schnell, 2018; van der Meer, 2010). Although attitudes and behavior are closely related, attitudes do not completely predict behavior. It should be stressed that attitudes towards corruption and willingness to engage in anti-corruption actions need to be distinguished.

\subsection{Dependent variable: the propensity to report corruption}

The propensity to report corruption is the dependent variable in this study. To measure it, we asked the survey respondents if they have ever reported a case or situation that involved corruption with three options 'yes', 'no' and 'may be' where among the respondents 197 (78.8\%) said 'no' and 31 (12.4\%). The higher rate of negative responses shows that there is lack of trust in government establishes anti-corruption agencies and thus there is need to build citizen trust and empower their engagement in anti-corruption. This incident may also be attributed to less awareness of the laws and policies that govern corruption practices. We also noticed a lack of knowledge of the law where $63.8 \%$ of the responses are not aware of the laws against corruption thus hindering their propensity to report and confront corruption cases in Uganda. The finds are in line with (Strimbu O, 2017) who argues that less citizen involved in fighting corruption is largely due to lack of trust, ignorance of the laws and lack of transparency in public sector decisions thus increasing corruption tendencies..

\subsection{Independent variables}

The first independent variable is citizen trust, for which two measurements are used in our survey questionnaire: trust in Government anti-corruption agencies and civil society organizations and trust in laws, judiciary and media. First, the survey asked the respondents 'To what extent do you trust Government anti-corruption agencies, Civil Society Organizations, NGOs, Media and the Church in the fight against corruption?' On a fivepoint likert scale of 'Not at all' (1) to 'To a very great extent' (5) levels were provided. Results show that the mean of the answers to these questions is 2.32 and 3.37 with a standard deviation of 1.047 and 1.163 respectively. As reported in Table 1, among the respondents, majority responded that they do not trust the government established anti-corruption agencies as compared to civil society and the media. This is shows that government should work hand in hand with civil society to improve citizen participation in anti-corruption. The second independent variable corruption tolerance is measured through some selected incidences that bare corruption practices as shown in Table 2. The original scale provided five options 'I find this completely acceptable' to 'I find this unacceptable'. Not surprisingly, most respondents have a low tolerance of corruption $(52.4 \%)$ and are aware of what constitutes corruption a shown in Table 3. Given the uneven distribution, the answers were collapsed into two categories "I find this completely acceptable" and "I find this unacceptable'. The other part respondents were required to give their perceptions of the government's anti-corruption effort which consisted of a prospective assessment. This involved asking the respondents 'Would you say that the government is pretty much run by a few big interests looking out for themselves, as opposed to being run for the benefit of all the people?' with 4 representing 'very much likely' (47.4\%) and 1 denoting 'not at all' (15\%). The majority of the respondents rated the government's performance very ineffective, and the answers are reported in Table 2 and 3 which also shows the descriptive analysis of the other independent variables and the frequencies and percentages. 
Table 2: Descriptive Analysis

\begin{tabular}{|l|c|c|c|c|}
\hline Variables & Min & Max & Mean & STD \\
\hline Age & 1 & 5 & 2.35 & .988 \\
\hline Gender (1=Female, 2=Male, 3=Prefer not to say) & 1 & 3 & 1.46 & .515 \\
\hline Education level (6=highest). & 1 & 6 & 4.63 & 1.233 \\
\hline Employment status (7=highest) & 1 & 7 & 2.78 & 1.777 \\
\hline Marital Status & 1 & 5 & 1.87 & .924 \\
\hline Income source & 1 & 5 & 2.54 & 1.181 \\
\hline Region & 1 & 5 & 2.03 & 1.509 \\
\hline Anti-Corruption Laws (1=yes) & 1 & 2 & 1.64 & .482 \\
\hline Anti-Corruption agencies(1=yes) & 1 & 2 & 1.25 & .432 \\
\hline Trust CSOs, media (5=to very great extent) & 1 & 6 & 3.37 & 1.047 \\
\hline Trust Government Agencies (5=to very great extent) & 1 & 6 & 2.32 & 1.163 \\
\hline Anti-corruption effectives (5=strongly agree) & 1 & 6 & 2.97 & 1.290 \\
\hline Report corruption (1=yes) & 1 & 3 & 1.94 & .440 \\
\hline Followed any anti-corruption cases (1=yes) & 1 & 3 & 1.49 & .712 \\
\hline Engaged in Anti-corruption discussion/networks (1=yes) & 1 & 2 & 1.74 & .440 \\
\hline
\end{tabular}

Table 3: Descriptive statistics for independent variables

\begin{tabular}{lccccc}
\hline Variables & N & Min & Max & Mean & SD \\
\hline Corruption Awareness & & & & & \\
CA1 & 244 & 1 & 2 & 1.64 & .482 \\
CA2 & 247 & 1 & 2 & 1.25 & .432 \\
CA3 & 244 & 1 & 4 & 2.07 & .886 \\
CA4 & 246 & 1 & 4 & 1.63 & .806 \\
CA5 & 245 & 1 & 4 & 2.16 & 1.018 \\
CA6 & 243 & 1 & 4 & 1.66 & .772 \\
Citizen Trust & & & & & \\
CT1 & 249 & 1 & 5 & 3.29 & .973 \\
CT2 & 249 & 1 & 6 & 3.37 & 1.047 \\
CT3 & 246 & 1 & 6 & 2.32 & 1.163 \\
CT4 & 248 & 1 & 6 & 2.97 & 1.290 \\
CT5 & 245 & 1 & 6 & 3.62 & .983 \\
CT6 & 245 & 1 & 6 & 2.00 & .875 \\
CT7 & 245 & 1 & 5 & 1.98 & 1.004 \\
CT8 & 245 & 1 & 5 & 3.94 & 1.062 \\
CT9 & 243 & 1 & 5 & 4.02 & 1.135 \\
Corruption Tolerance & & & & & \\
CTo1 & 248 & 1 & 5 & 3.88 & 1.068 \\
CTo2 & 248 & 1 & 5 & 4.04 & 1.147 \\
CTo3 & 246 & 1 & 5 & 3.64 & 1.200 \\
CTo4 & 247 & 1 & 5 & 3.76 & 1.402 \\
CTo5 & 245 & 1 & 5 & 3.87 & 1.355 \\
CTo6 & 247 & 1 & 5 & 3.78 & 1.018 \\
\hline
\end{tabular}

From the data, most respondents have less tolerance for corruption behavior and this is attributed to their knowledge of what is wrong and not acceptable in society. Respondents in particular as shown in table 4 are concerned about corruption that entails rule-breaking within the limits of existing regulations which violates legal rules or present a very biased enforcement of the rules (van den Berg \& Noorderhaven, 2016). 
Deborah Sarah Nakirijja \& Liu Oijun, Adv. J Social Sci.; Vol. 7, Issue 1, pp: 145-162, 2020

Table 4: Frequency and percentage distribution of corruption tolerance and awareness

\begin{tabular}{|c|c|c|c|}
\hline Variables & Scale & Frequency & Percentage (\%) \\
\hline \multirow{4}{*}{$\begin{array}{l}\text { It is corruption when a person } \\
\text { responsible for procurements } \\
\text { in an organization buys } \\
\text { computers for the office from } \\
\text { a company owned by his son } \\
\text { (or any other close friend or } \\
\text { relative). }\end{array}$} & I agree completely & 69 & 27.6 \\
\hline & I agree & 106 & 42.4 \\
\hline & I disagree & 51 & 20.4 \\
\hline & I disagree completely & 18 & 7.4 \\
\hline \multirow{4}{*}{$\begin{array}{l}\text { It is corruption when a } \\
\text { businessman gives a donation } \\
\text { to a political party in return } \\
\text { for a favorable decision. }\end{array}$} & I agree completely & 131 & 52.4 \\
\hline & I agree & 86 & 34.4 \\
\hline & I disagree & 18 & 7.2 \\
\hline & I disagree completely & 11 & 4.4 \\
\hline \multirow{4}{*}{$\begin{array}{l}\text { It is corruption when an } \\
\text { official accepts a gift after } \\
\text { providing a service }\end{array}$} & I agree completely & 81 & 32.4 \\
\hline & I agree & 73 & 29.2 \\
\hline & I disagree & 62 & 24.8 \\
\hline & I disagree completely & 29 & 11.6 \\
\hline \multirow{4}{*}{$\begin{array}{l}\text { It is corruption when an } \\
\text { official accepts money, a gift } \\
\text { or a favor in return for not } \\
\text { fining a person or for } \\
\text { expediting paperwork. }\end{array}$} & I agree completely & 117 & 46.8 \\
\hline & I agree & 101 & 40.4 \\
\hline & I disagree & 15 & 6.0 \\
\hline & I disagree completely & 10 & 4.0 \\
\hline \multirow{5}{*}{$\begin{array}{l}\text { A public official makes a } \\
\text { promise to a businessman that } \\
\text { in return for a favor he will } \\
\text { persuade a higher-ranking } \\
\text { public official at the ministry } \\
\text { to pass a decision in favor of } \\
\text { a project related to the } \\
\text { businessman }\end{array}$} & I find this completely acceptable & 12 & 4.8 \\
\hline & I find this acceptable & 22 & 8.8 \\
\hline & Neutral & 19 & 7.6 \\
\hline & I find this unacceptable & 125 & 50.0 \\
\hline & I find this completely unacceptable & 70 & 28.0 \\
\hline \multirow{5}{*}{$\begin{array}{l}\text { A businessman offers a } \\
\text { vacation abroad to the } \\
\text { principal of an elite school, } \\
\text { expecting the principal to } \\
\text { admit his son to the school in } \\
\text { return. }\end{array}$} & I find this completely acceptable & 13 & 5.2 \\
\hline & I find this acceptable & 16 & 6.4 \\
\hline & Neutral & 32 & 12.8 \\
\hline & I find this unacceptable & 75 & 30.0 \\
\hline & I find this completely unacceptable & 112 & 44.8 \\
\hline \multirow{4}{*}{$\begin{array}{l}\text { An official uses his or her } \\
\text { office car for personal trips }\end{array}$} & I find this completely acceptable & 42 & 16.8 \\
\hline & Neutral & 27 & 10.8 \\
\hline & I find this unacceptable & 85 & 34.0 \\
\hline & I find this completely unacceptable & 93 & 37.2 \\
\hline \multirow{4}{*}{$\begin{array}{l}\text { A businessman calls an } \\
\text { official whom he knows, } \\
\text { asking him or her to expedite } \\
\text { some paperwork that has } \\
\text { been delayed. }\end{array}$} & I find this completely acceptable & 36 & 14.4 \\
\hline & Neutral & 26 & 10.4 \\
\hline & I find this unacceptable & 81 & 32.4 \\
\hline & I find this completely unacceptable & 102 & 40.8 \\
\hline
\end{tabular}


Analyzing Citizens' Propensity to Confront and Report Corruption: Evidence from Uganda

\section{Discussion}

Corruption is a major threat facing Uganda, it undermines institutions efforts, it destroys lives and communities, it translates into human suffering (citizens being extorted for bribes to access public services), it leads to failure in the delivery of basic services (like clean water, electricity, education, healthcare, and personal safety), it derails the building of essential infrastructure and, finally, it generates popular anger among citizens in public officials that threatens to further destabilize societies and exacerbate violent conflict

Reporting corruption is both an indicator of citizens' ability to battle corruption and an estimation of their trust in the government's anti-corruption work. The more citizens report cases of corruption, the more potential it shows in fighting corruption to a bare minimum. Exposing and confronting corruption by the citizens may also exert social pressure on the government to make it more determined to step up its anti-corruption efforts. Basically, rich and reliable information provided by citizens enables the government to detect corruption quickly. Higher reporting rates against corruption, consequently improves the effectiveness of governance. In many developing countries, the failure in controlling corruption is attributable to the fact that stakeholders are reluctant to report corruption. Some citizens may believe that reporting corruption would not bring any change and they may also fear negative consequences such as vengeance (TI-Kenya, 2017). Even in some more advanced economies, insufficient legal protection may prevent public sector employees from reporting workplace transgression (Michels, 2011).

There were other control variables as included in Table 1. For example, how citizens perceive the causes of corruption may affect their willingness to report corruption. If corruption is considered as deeply rooted in the government institutions and the less implementation of the set laws and policies, they therefore assume that it is difficult to prevent and hence less likely to report corruption. The frequently mentioned causes of corruption in the survey findings are weak law enforcement, lack of transparency in Government processes, lack of trust in established agencies and institutions and individual greed. Demographic variables (education level, monthly income, employment status, age and gender) are also controlled for. Corruption experiences may affect the willingness to report corruption, too. But without knowing if those who experienced corruption were victims or beneficiaries of corruption transactions, it would be difficult to predict how they might respond when confronting corruption (Gong \& Xiao, 2017). In addition, the extent to which citizens are familiar with reporting mechanisms may have an impact on reporting. The more familiar with the procedures, the more likely people will report corruption.

The findings highlight several crucial issues for the improvement of citizen satisfaction. First, the roles of transparency and trust need to be taken into account as important factors in developing policy aimed at reducing corruption and improving citizen satisfaction. This suggests that a successful campaign of anticorruption must involve enhancing understanding of corruption and building confidence in the party-state's strategy on anticorruption. Practitioners should consider the full menu of design choices for engaging citizens. The "democracy cube" is one way of reflecting on the many other ways of designing participation different kinds of participants; different ways of speaking, hearing, and exchanging information (e.g., small groups); and different levels of empowerment.

For Uganda there is need for the government to invest more on Civic education on anti-corruption laws and the role of citizens in observing them. In addition, establishment and strengthening of the internal integrity departments across key government institution should be pursued. The Government should embrace a multisectoral approach to the fight against corruption and this can be implemented through complementing the various stakeholders' efforts. Because of the lack of protection for whistle-blowers or because of low trust in the government's sincerity in fighting corruption, low levels of tolerance of corruption often do not translate into the propensity to report corruption. If the public does not report corruption because the government has performed poorly in controlling corruption, the government's effort may encounter even more difficulties. This 
will then cause a vicious circle of poor anti-corruption performance and lack of support for the government to fight corruption.

Corruption is hindering Africa's economic, political and social development. It is a major barrier to economic growth, good governance and basic freedoms, such as freedom of speech or citizens' right to hold governments to account (TI, 2019). The 2019 Global Corruption Barometer Africa (TI, 2019) shows that the range of corruption challenges that African citizens face is complex and multifaceted, requiring fundamental and systemic changes. It also highlights that while most people surveyed felt corruption had increased in their country, a majority felt that they, as citizens, could make a difference in the fight against corruption. Corruption in Uganda is widespread and seen as one of the greatest obstacles to the country's economic development as well as to the provision of quality public services (Beddow, 2017; Krawczyk \& Sweet-Cushman, 2017; Martini, 2013; The World Bank, 1994). Corruption related challenges in Uganda for instance stem from a weak separation between the public and private spheres, leading to extensive clientelistic practices and patronage, as well as widespread political corruption. Such corruption challenges are exacerbated by weak law enforcement, which fuels a culture of impunity, particularly with regards to high-ranking officials involved in corruption schemes.

While doing field research, we interviewed staff at Transparency International Uganda (TI-Uganda) to better understand civil society efforts in engaging citizens in anti-corruption interventions. TIU is the national chapter of Transparency International in Uganda. Created in 1993, and officially accredited as a national chapter in 1996, TI-Uganda has contributed to the goal of building a society free of corruption by promoting anticorruption reform in the country, increasing public awareness, and empowering citizens to combat it (Transparency International Uganda 2016). Currently, TI-Uganda works in collaboration with civil society and other NGOs to improve transparency and accountability in the Ugandan government and in the private sector. Citizens are encouraged to participate in the reporting of corruption cases through their Toll-free line or call center. This is also done through community outreaches, dialogues, jingles and radio talk shows to promote an inclusive participation of all citizens at all levels in the reporting of corruption cases in Uganda. According to a discussion with TIU Program staff, there is a gender gap and disparities in participation where male tend to take up responsibilities and participate fully compared to the female. This they attribute strongly to gender stereotyping and roles that hinder women from full participation in the public sphere.

For Sööt \& Rootalu, 2012, trust in institutions, age and nationality are the most important individual factors to influence public officials' awareness of corruption and the extent to which they are ready to condemn corrupt and unethical behavior. Their findings of the current study seem to lend credence to the assumption that those with higher levels of trust in state institutions such as the police, courts and politicians would have higher expectations for them and would place more confidence in those institutions and their representatives. To formulate effective anti-corruption policies, it is crucial to know what influences people's attitudes towards corruption.

The literature on what motivates citizens to confront and report corruption is still scanty and with little insight on how to manage interventions on corruption while fully engaging the citizens. A survey by Transparency International revealed that only 16 percent of respondents from Rwanda said that they had filed complaints against bribery, and the rates were even lower in Uganda (6.9\%) and Burundi (3.2\%) (TI, 2013; Ting Gong and Hanyu Xiao, 2017). The question of why citizens become involved in the anti-corruption process has occupied public administration scholars of recent. Prior researchers (Sööt \& Rootalu, 2012; Gillanders \& Neselevska, 2017; Ting Gong and Hanyu Xiao, 2017; Nelson \& Afonso, 2019; Neshkova \& Kalesnikaite, 2019) have studied the patterns underlying citizens' ability to confront and report corruption and its impact on the sustainability of established anti-corruption strategies. The core of their research lies in the distinction between the attitude towards corruption and actual anti-corruption behavior. In addition, other research has emphasized the 
Analyzing Citizens' Propensity to Confront and Report Corruption: Evidence from Uganda

importance of socially perceived anti-corruption governance and its effects on government formulated institutions. In this case, citizens' willingness to participate in anti-corruption relates positively with experience of corruption (awareness), and tolerance of corruption.

\section{Conclusions}

In order to engage citizens, government and the relevant stakeholders should be clear about the intention for convening citizens and design engagement in a way that envisions a clear path leading from engagement to the satisfaction of that intention. It is important to design participation in ways that its outcomes are meaningful to participants. Frustration, cynicism, or apathy can be the results of a poorly designed public engagement process in which participants' hopes for learning, working, or accomplishing some goal are disappointed by a process that is futile, in which the relevant decisions have been made elsewhere by someone else, or in which the choices and stakes are trivial. Citizen participation is not just about policy; it is also deeply political. Substantial citizen engagement will be sustained over time only if citizens come to support the institutions and practices of participation that is, if they grow into a constituency that will not just engage but also defend against efforts to reduce participation.

\section{Declaration}

\subsection{Acknowledgements}

We thank all the respondents at all levels for their assistance with obtaining primary data and for their inputs that greatly improved the manuscript, in addition to sharing their cases with us during the course of this research

\subsection{Informed Consent}

Consent of respondents was sought from each respondent prior to engagement so that they don't feel coerced; the researchers had to request for consent from the respective respondents. An ethical form was signed and presented to every respondent and administrator at the time of interview.

\subsection{Competing Interests}

The authors declare that no conflict of interest exist in publication of this article

\section{How to Cite this Article:}

Nakirijja, D. S., \& Oijun, L. (2020). Analyzing Citizens' Propensity to Confront and Report Corruption: Evidence from Uganda. Advanced Journal of Social Science, 7(1), 145-162. https://doi.org/10.21467/ajss.7.1.145-162

\section{References}

Bank, W. (2006). World Bank- Civil Society Engagement. The International Bank for Reconstruction and Development.

Beddow, R. (2017). Corruption Perceptions Index. Transparency International, 107-114. https://doi.org/978-3-943497-18-2

Bissessar, O. O. and N. (2014). Challenges to Democratic Governance in Developing Countries: A Symptom of Leadership and Institutional Failure. Public Administration, Governance and Globalization, 19-36. https://doi.org/10.1007/978-3-319-03143-9

Brinkerhoff, D. W., \& Johnson, R. W. (2009). Decentralized local governance in fragile states: Learning from iraq. International Review of Administrative Sciences, 75(4), 585-607. https://doi.org/10.1177/0020852309349424

Brinkerhoff, D. W., \& Wetterberg, A. (2015). Gauging the Eff ects of Social Accountability on Services, Governance, and Citizen Empowerment. Public Administration Review, 76(2), 274-286. https://doi.org/10.1111/puar.12399.of

Choi, T., \& Robertson, P. J. (2018). Contributors and Free-Riders in Collaborative Governance: A Computational Exploration of Social Motivation and Its Effects. Journal of Public Administration Research and Theory, 1-20. https://doi.org/10.1093/jopart/muy068

Fawcett, S. B., Francisco, V. T., Schultz, J. A., \& Richter, K. (1995). Using empowerment theory in collaborative partnership for community health and development. American Journal of Community Psychology, (November). https://doi.org/10.1007/BF02506987

Fourie, D. J., \& Kakumba, U. (2011). Assessing the Role and Capacity of Civil Society Organisations in Holding Local Government Accountable in Uganda. African Journal of Public Affairs, 4(2), 54-66.

Fung, A. (2006). Varieties of Participation in Complex Governance. Public Administration Review, Special Is(December).

Fung, A. (2015). Putting the Public Back into Governance: The Challenges of Citizen Participation and Its Future. Public Administration Review, $x x, 1-10$. https://doi.org/10.1111/puar.12361.Putting 
Deborah Sarah Nakirijja \& Liu Oijun, Adv. J Social Sci.; Vol. 7, Issue 1, pp: 145-162, 2020

Gaventa, J. (2004). Strengthening Participatory Approaches to Local Governance : Learning the Lessons from Abroad. National Civic Review, 1627.

Gillanders, R., \& Neselevska, O. (2017). PUBLIC SECTOR CORRUPTION AND TRUST IN THE PRIVATE SECTOR. Journal of International Development. https://doi.org/10.1002/jid.3306

Gong, T., \& Xiao, H. (2017). Socially Embedded Anti-Corruption Governance: Evidence from Hong Kong. Public Administration and Development. https://doi.org/10.1002/pad.1798

Grimmelikhuijsen, S., \& Knies, E. (2017). Validating a scale for citizen trust in government organizations. International Review of Administrative Sciences, 83(3), 583-601. https://doi.org/10.1177/0020852315585950

Guo, X., \& Tu, W. (2017). Corruption tolerance and its influencing factors-the case of China's civil servants. Journal of Chinese Governance, 2(3), 307-328. https://doi.org/10.1080/23812346.2017.1342897

Hillier, A. V. \& D. (2019). ENSURING IMPACT: THE ROLE OF CIVIL SOCIETY ORGANISATIONS IN STRENGTHENING WORLD BANK DISASTER RISK FINANCING DISCUSSION PAPER. International Development Association, (March).

Hough, D. (2013). Corruption, Anti-Corruption and Governance.

IGG, I. of G. (2003). First annual report on corruption in Uganda. https://doi.org/10.1038/cddis.2011.1

Jerusalem, E. (2013). Trust in government, policy effectiveness and Governance Agenda. OECD, 19-38.

Jilke, S. (2017). Citizen satisfaction under changing political leadership : The role of partisan motivated reasoning. Governance, (November 2016). https://doi.org/10.1111/gove.12317

Kahana, N., \& Qijun, L. (2010). Endemic Corruption. European Journal of Political Economy, 26(1), 82-88. https://doi.org/10.1016/j.ejpoleco.2009.09.001

Kaluya, M. D., \& Elliott, E. W. (2018). Corruption in Uganda : A Comparative Study of Citizens ' and Public Officials 'Perceptions. 9(1).

Kaufmann, D. (2005). Myths and Realities of Governance and Corruption. Ssrn, 81-98. https://doi.org/10.2139/ssrn.829244

Krawczyk, K. A., \& Sweet-Cushman, J. (2017). Understanding political participation in West Africa: the relationship between good governance and local citizen engagement. International Review of Administrative Sciences, 83(1_suppl), $136-155$. https://doi.org/10.1177/0020852315619024

Laegreid, T. C. and P. (2016). Trust in Government: The Relative Importance of Service Satisfaction, Political Factors, and Demography. Public Perfomance and Management Review, 28(4), 487-511.

Levin, C. swift and G. (1987). Empowerment: An Emerging Mental Health Technology. Journal of Primary Prevention, 8. https://doi.org/10.1007/BF01695019.

Martini, M. (2013). Uganda overview of corruption and anti corruption. U4 Expert Answer. Transparency International (Vol. U4).

Michels, A. (2011). Innovations in democratic governance: how does citizen participation contribute to a better democracy? https://doi.org/10.1177/0020852311399851

Morales, I. (n.d.). (International Political Economy Series) Susan Brown-Shafii (auth.)-Promoting Good Governance, Development and Accountability_Implementation and the WTO-Palgrave Macmillan UK (2011).

Mudacumura, G. M. (2014). Challenges to Democratic Governance in Developing Countries. 19-36. https://doi.org/10.1007/978-3-319-03143-9

Naidoo, J. (2015). Pedagogic strategies: Using empowerment theory to confront issues of language and race within mathematics education. Power and Education, 7(2), 224-238. https://doi.org/10.1177/1757743815586522

Nelson, K. L., \& Afonso, W. B. (2019). Ethics by Design: The Impact of Form of Government on Municipal Corruption. Public Administration Review, 00, 1-10. https://doi.org/10.1111/puar.13050

Neshkova, M. I., \& Kalesnikaite, V. (2019). Corruption and citizen participation in local government: Evidence from Latin America. Governance, (July 2018), 1-17. https://doi.org/10.1111/gove.12401

Nichols, S. L., Berliner, D. C., Damage, C., \& High, H. (2007). A Corrupt Argument. Journal of Public Administration Research and Theory, 677679. https://doi.org/10.1093/jopart/mum016

Ocheje, P. D. (2018). Norms , law and social change : Nigeria 's anti-corruption struggle, 1999 - 2017. Crime Law Soc Change, $1999-2017$.

Park, H., \& Blenkinsopp, J. (2011). The roles of transparency and trust in the relationship between corruption and citizen satisfaction. International Review of Administrative Sciences, 77(2), 254-274. https://doi.org/10.1177/0020852311399230

Porumbescu, G. A. (2016). Linking public sector social media and e-government website use to trust in government. Government Information Quarterly, 33(2), 291-304. https://doi.org/10.1016/j.giq.2016.04.006

Riley, D., \& Fernández, J. J. (2014). Beyond strong and weak: rethinking postdictatorship civil societies. AJS; American Journal of Sociology, 120(2), 432-503. https://doi.org/10.1086/678272

Rubalcaba Medina, E. (2017). Structural Analysis of Civil Society Organizations (CSO): Developing CSOs' Organizational Capacities in Mexico. World Futures Review, 9(3), 142-158. https://doi.org/10.1177/1946756717715653

Schnell, S. (2018). From information to predictability: transparency on the path to democratic governance. The case of Romania. International Review of Administrative Sciences, 84(4), 692-710. https://doi.org/10.1177/0020852316648756

Sheryazdanova, G., \& Butterfield, J. (2017). E-government as an anti-corruption strategy in Kazakhstan. Journal of Information Technology and Politics, 14(1), 83-94. https://doi.org/10.1080/19331681.2016.1275998

Song, M., \& Meier, K. J. (2018). Citizen Satisfaction and the Kaleidoscope of Government Performance: How Multiple Stakeholders See Government Performance. Journal of Public Administration Research and Theory, (March), 1-17. https://doi.org/10.1093/jopart/muy006

Sööt, M., \& Rootalu, K. (2012). Institutional trust and opinions of corruption. Public Administration and Development, 95, 82-95. https://doi.org/10.1002/pad

Strimbu O, G. P. (2017). Does transparency reduce political corruption? Journal of Public Economic Theory, (November 2016), 1-13. https://doi.org/10.1111/jpet.12265 
Analyzing Citizens' Propensity to Confront and Report Corruption: Evidence from Uganda

Tang, N., Ding, Z., \& Xu, Y. (2018). Corruption and Anti-Corruption Research in China: A Critical Review of Chinese Top Journal Publications (1989-2017). Chinese Public Administration Review, 9(2), 79. https://doi.org/10.22140/cpar.v9i2.167

Tarling, N. (2005). Corruption and good governance in Asia. Corruption and Good Governance in Asia, 10, 1-282. https://doi.org/10.4324/9780203029343

The World Bank. (1994). Governance: The World Bank's Experience. In Development in Practice.

TI-Kenya. (2017). The East African Bribery Index. In Transparency International Kenya.

TI. (2019). Global Corruption Barometer Africa 2019 Citizens' Views and Experiences of Corrption.

UBOS. (2016). National Service Delivery Survey 2015 Report. Retrieved from http://www.ubos.org/onlinefiles/uploads/ubos/pdf documents/2015 NSDS report.pdf

van den Berg, P., \& Noorderhaven, N. (2016). A Users' Perspective on Corruption: SMEs in the Hospitality Sector in Kenya. African Studies, 75(1), 114-132. https://doi.org/10.1080/00020184.2015.1129138

van der Meer, T. (2010). In what we trust? A multi-level study into trust in parliament as an evaluation of state characteristics. International Review of Administrative Sciences, 76(3), 517-536. https://doi.org/10.1177/0020852310372450

Walle, V. De. (2010). Public Trust in Government in Japan and South Korea: Does the Rise of Critical Citizens Matter? Public Administration Review, 801-810.

Walle, S. Van De, Roosbroek, S. Van, \& Bouckaert, G. (2008). Trust in the Public Sector: is there any evidence for a long-term decline? International Review of Administrative Sciences, 74(1), 47-64. https://doi.org/10.1177/0020852307085733

Zimmerman, M. A. (2000). Empowerment Theory: Psychological, Organizational and Community Levels of Analysis. Handbook of Community Psychology, (1984), 43-63.

Publish your research article in AIJR journals-

- $\quad$ Online Submission and Tracking

- Peer-Reviewed

- Rapid decision

- Immediate Publication after acceptance

- Articles freely available online

- Retain full copyright of your article.

Submit your article at journals.aijr.in
Publish your books with AIJR publisher-

- Publish with ISBN and DOI.

- Publish Thesis/Dissertation as Monograph.

- Publish Book Monograph.

- Publish Edited Volume/ Book.

- Publish Conference Proceedings

- Retain full copyright of your books. Submit your manuscript at books.aijr.org 